\title{
Rönesans’tan Sürrealizme Resim Sanatının Tarihsel Gelişim Sürecinde Figür ve Kompozisyon*
}

\author{
The Figure and Composition in the Historical Development Process of the \\ Painting from the Renaissance to Surrealism
}

\section{Kani Ülger}

Doç. Dr. Cumhuriyet Üniversitesi Eğitim Fakültesi Güzel Sanatlar Eğitimi Bölümü Resim İş Eğitimi Anabilim Dalı, kulger@gmail.com

\footnotetext{
* Bu çalışmanın bir kısmı yazar tarafından, I. Uluslararası Güzel sanatlar ve Eğitimi Sempozyumunda (UGES) sözlü bildiri olarak sunulmuştur: 28-30 Nisan 2018, Cumhuriyet Üniversitesi, Sivas
}

\section{$\ddot{\mathbf{O z}}$}

$\mathrm{Bu}$ çalışmanın amacı, resim sanatının figür ve kompozisyon ögelerindeki gelişimi Rönesans döneminden Sürrealizm akımına kadar olan tarihsel süreç içinde incelemektir. Çalışmanın yöntemi ise alan yazın taraması biçimindedir. $\mathrm{Bu}$ amaçla araştırma konusu ile ilgili yayınlar taranmış, indirgeme tekniği kullanılarak çalışma örneklemi oluşturulmuştur. Araştırmanın sonucuna göre, Rönesans'tan Sürrealizme dek resimdeki figür ve kompozisyon ögelerinde biçim ve içerik bağlamında büyük bir değişim olduğu bulgusuna ulaşılmıştır. Bu değişime neden olarak ressamın tuvale aktarmak istediği duygu ya da düşünceyi ifade etmede figür ve kompozisyona biçeceği rol arayışı gösterilebilir. Bu arayış, hiç kuşkusuz, tarihsel süreç içindeki değişimden kaynaklanmakta ve söz konusu değişim duyarlı büyük sanatçıları daha çok etkileyebilmektedir. Bu değişimin etkisi altında ressam tuvaline duygu ya da düşüncesini aktarırken, en çok resmin temel ögelerinden figür ve kompozisyonda yeni ifade ve biçim arayışlarına girmekte ve bu etkiyi tuvaline yansıtmaya çalışmaktadır. Sonuç olarak, tarihsel süreç içindeki değişimin devam edeceğini öngördüğümüzde, resmin temel ögeleri olan figür ve kompozisyonda gelecekte de değişimin biçim-içerik bağlamında devam edeceğini söyleyebiliriz.

Anahtar Sözcükler: Rönesans, resim, figür, kompozisyon, piramidal yapı

\begin{abstract}
The aim of this study was to investigate the development in the painting regarding the figure and composition factors from Renaissance to Surrealism. The study method was the literature review conducted on publications with implementing a set of inclusion/exclusion criteria on these publications classified by hierarchical technique as related to research subjects. Consequently, it was observed that a big change in the figure and composition of the painting from the Renaissance to the Surrealism. This situation originates from the roles of the figure and composition formed by the painter under her/his thoughts or feelings. This role searching is determined mainly by the changing in the historical development that impresses the artists a lot. If it is considered that the changing in the historical development will follow in the next periods, then, it can be predicted that this changing will go on the painting in terms of the figure and composition factors.
\end{abstract}

Keywords: Renaissance, painting, figure, composition, pyramidal composition. 


\section{Giriş}

Resim sanatının yıllar boyunca en önemli sorunsallarından biri 'figür' ve buna bağlı olarak 'kompozisyon' ögeleridir. Figür ve kompozisyonun resim sanatı için önemini binlerce yıl öncesinden yapılan mağara resimlerinde bile görmek mümkündür. Fransa'daki ünlü Lascaux Mağarasında bulunan 17.000 yıllık duvar resimlerini gören İspanyol ressam Pablo Picasso bu resimler karşısındaki beğenisini "Yeni hiçbir şey öğrenmemişiz" (Özbaşaran Dede, 2016) biçiminde ifade ederken, belki de bu resimlerde öne çıkan figür ögesine olan beğenisini ortaya koymuştu. Tepecik (2002)'e göre, insanların yazılı belgeler bırakmadan mağaraların duvarlarına çizilen resimlerle görsel eserler bırakmalarının olası en önemli nedenlerinden biri; kendilerini ifade etme ihtiyacı olduğu söylenebilir. Resimde ifadeyi yansitmada en önemli öge olarak önce figür, izleyen dönemlerde figür ile birlikte kompozisyon olmuştur. Resimde figür ve kompozisyonun bir nevi özne ve nesne bağlamında ressam tarafından ele alınışı ve sunumu her zaman önemli bir konu olmuştur. Bu konunun resim sanatında belirgin bir biçimde öne çıkışı Rönesans (Yeniden Doğuş) Dönemine rastlar. Erken Rönesans Döneminde, Csikszentmihalyi (2013, s. 36)'nin aktardığı gibi, ressamın eserinde başlangıç noktası “öznel ifade” idi. Bu dönemde öznel ifadeyi en iyi yansıtan görsel öge olarak figür, özellikle insan figürünün ön planda olduğunu söyleyebiliriz. Bu durum, Rönesans'ın ilerleyen yıllarında, resimde kompozisyon ögesinin de önem kazanmasıyla birlikte genişlemiştir. Resim sanatında bu tür bir genişleme, resim sanatında önemli bir sorunu da beraberinde getirmiştir. $\mathrm{Bu}$ sorun kısaca, 'hangi figürü nasıl bir kompozisyonda resmedebiliriz' biçiminde özetlenebilir. Böylece bu soruya yanıt ararken, aktarılmak istenilen ifadeyi en iyi biçimde yansıtabilmek için, resimde figür ve kompozisyon ögelerinin oynayacakları roller açısından gelişim süreci de başlamış olmaktadır.

Bu çalışma kapsamında resim sanatının çok önemli bir dönemi olan Rönesans'tan Sürrealizme kadar olan tarihsel gelişim sürecinde, resimde figür ve kompozisyon açısından yaşanan gelişime dair bir inceleme yapılmıştır. Buna göre araştırmada "Resim sanatının Rönesans'tan Sürrealizm dönemine kadar olan tarihsel süreç içinde figür ve kompozisyon ögeleri açısından gelişimi nasıldır?" sorusuna yanıt aranmıştır.

\section{Yöntem}

Bu çalışma bir alan yazın (literatür) taramasıdır. Buna göre, resim sanatında figür ve kompozisyon ögeleri açısından yer alan kaynaklar taranmış ve bir araştırma tekniği olarak araştırılan kriterlere (figür ve kompozisyon) indirgeme yapılarak, konuyla doğrudan bağlantılı kaynaklar örneklem olarak ele alınmıştır. Ayrıca, Hiyerarşi yöntemiyle (Butler \& Kline, 1998) bu örneklem, kaynaklar bağlamında 'figür ve kompozisyon' terimleri açısından kategorik olarak üstten alta doğru sınıflandırılarak en elverişli kaynaklar veri toplama araçları olarak belirlenmiştir.

\section{Bulgular ve Yorum}

13. Yüzy1l Avrupa'sında Geç Gotik (1280-1400) üslup Rönesans'ın habercisi olduğundan, 'Ön Rönesans' olarak da adlandırılmaktadır (Varlık Şentürk, 2012, s. 27). Bu dönem resimlerinde görülen figürler belli bir oranda hacim kazanmış, resimdeki altın yaldızlı arka plan yerini mimari eleman ve doğa görünümlerine bırakmıştır. İtalya'da bu dönem sanat okullarından 14. Yüzyıl Floransa Okulu, biçimci yaklaşımı ve insan figürünü gerçeğe yakın betimleme kaygılarıyla öne çıkmıştır (Varlık Şentürk, 2012, s. 28). 


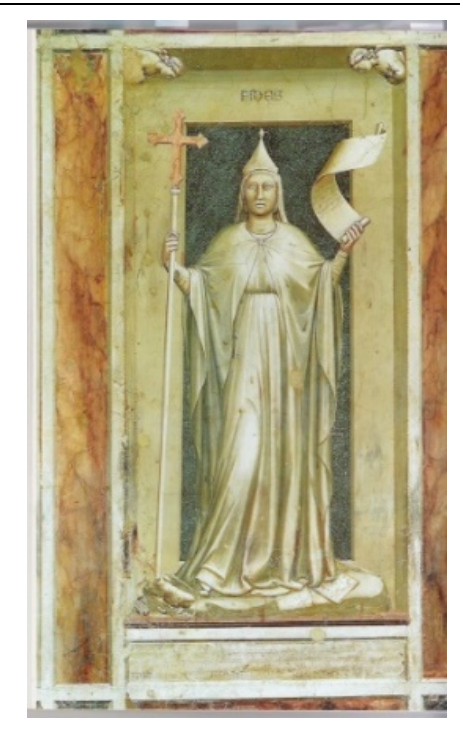

Görsel 1. Giotto di Bondone, 1305 dolaylarl, İnanç / Faith

Floransa Okulu'nun en önemli temsilcisi Giotto'dur (1266-1337). Giotto'nun kompozisyon kaygis1, espas ilişkileri, psikolojik anlatımda görülen duyarlılık, resimsel mekân arayışları ve açık-koyu renk ilişkileri ile oluşan hacim etkileri ile figürü gerçeğe yaklaştırmayı amaçlamıştır. Bu bağlamda Giotto (Di Bondone)'nun çalışmalarının özgünlüğü gerçekliği yansıtma becerisinden kaynaklandığı söylenebilir (Labno, 2008, s. 9).

Giotto mekânsal birlik etkisini arttırmak için farklı renkler kullanmıştır (Labno, 2008, s. 12). 14. yüzy1l İtalyan resminde görülen sslak sıva üzerine yapılan resimler olan fresklerde (Ormond, 2011, s. 572) bu değişim gözlenmektedir. Giotto di Bondone, 1302-1305 yılları arasında İtalya'nın Padova kentinde küçük bir kilise olan La Cappella degli Scrovegni'nin (Cappela dell' Arena) duvarlarına yaptığı fresklerde (Akademi Portal, 2016) figürlere hacim ve perspektif kısaltım kullandı. Bu fresklerle birlikte resimde ilk kez kumaş kıvrımlarındaki ışık-gölgeyi gözlemliyoruz (Görsel 1). Bundan dolayı, Giotto'yu resimde hacimsellik yanılsaması vermede, resim sanatını yeniden keşfeden ilk ressam (Gombrich, 2004, s. 201) olarak niteleyebiliriz.

Ön Rönesans döneminde, hem klasik dönemden hem de Ortaçağ' dan üslupça ve ikonografik olarak faklı yeni ifade formları gerekti. Bu durum Rönesans sanatının gerçek anlamı ve işlevini oluşturdu (Labno, 2008, s. 6). Bu bağlamda Giotto'nun resimde ilk kez perspektif kısaltım ve 1şık-gölgeyi kullandığını görüyoruz. Giotto'nun figürde hacim ve perspektif kısaltım tekniğini kullanmasıyla birlikte resim sanatında 'figür' ögesinde değişim başlamış oldu.

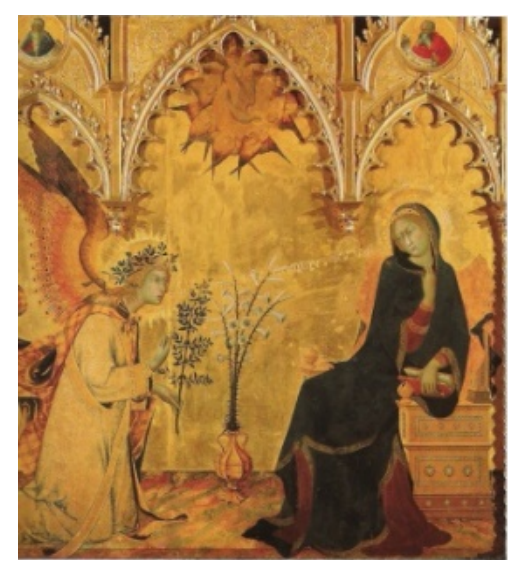

Görsel 2. Simone Martini ve Lippo Memmi, 1333, Meryem'e Müjde / The Annunciation 
Rönesans Döneminde ressamlar figürleri belli bir düzene göre yerleştirme sanatını Ortaçağ resim geleneğinden öğrenmişlerdi. Ancak bunu nesnelerin gerçek biçimini ve oranlarını dikkate almayarak ve mekânı tamamen unutarak yapıyorlardı (Gombrich, 2004, s. 212). Buna rağmen, Simone Martini ve Lippo Memmi’nin (1333) "Meryem'e müjde" adlı resminde (Görsel 2) olduğu gibi XIV. yüzyılın idealleri ve Giotto'nun buluşları devam ettirilmiş ve böylece ortaçağ resim sanatının da sonuna gelinmiş oldu. Bu andan itibaren bir dönem kapanmış, yeni bir dönem olan Rönesans'a girilmiş olunuyordu (Gombrich, 2004, s. 213-221).

Rönesans (1400-1580) döneminde geliştirilen “çizgisel perspektif”i Brunelleschi'ye borçluyuz (Gombrich, 2004, s. 229). Floransa'lı Filippo Brunelleschi (1377-1446), mimarlıkta Rönesans tarzını oluşturan bir mimar aynı zamanda heykeltıraştı (Filippo Brunelleschi, 2015). Brunelleschi'nin ressam arkadaşlarından Masaccio (1401-1428) "Kutsal üçlü” (Ruhül Kudüs; Meryem ve vaftizci Yahya ile bağışçıların bulunduğu resim) adlı freskoda (Görsel 3) perspektifi ilk kez kullanarak büyük bir devrim yapmıştı (Gombrich, 2004, s. 229).

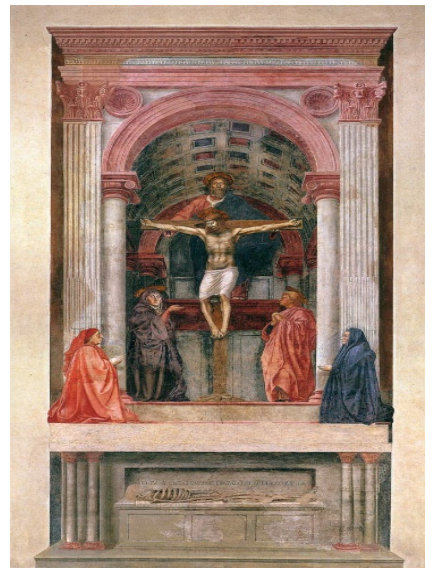

Görsel 3. Masaccio, 1425-28, Kutsal Üçlü / Holy Trinity

Floransa Okulunun öncülerinden olan Masaccio (1401-1428), Giotto'nun başlattığı resimde mekân ve derinlik problemini belirgin bir biçimde çözerek, resimlerinde üç boyutluluk etkisi veren mekânlarıyla dikkat çekmiştir (Varlık Şentürk, 2012, s. 45). Masaccio'nun resimlerinde görülen mekân ve figürde belirgin olarak gözlemlenen hacimsellik ve perspektif resme öyle bir yerleşmişti ki, Labno'nun (2008, s. 14-17) deyimiyle bu durum resim sanatında devrim niteliği kazanacaktı.

İzleyen dönemde Paola Uccello'nun (1397-1475) San Romano savaşını (1432) betimlediği resimde yere saçılmış kırık mızrakların düzenlenişi de çizgisel perspektifin ne derece resme girdiğini göstermesi açısından önemlidir (Görsel 4). Resme dikkatlice bakınca yere saçılmış kırık mızrakların ortak kaçış noktasını çok açık biçimde gösterdiğine tanık oluyoruz (Gombrich, 2004, s. 256). Bu durum Rönesans dönem resminde figür ve kompozisyonda perspektif açısından görülen değişimi göstermesi bakımından önemlidir.

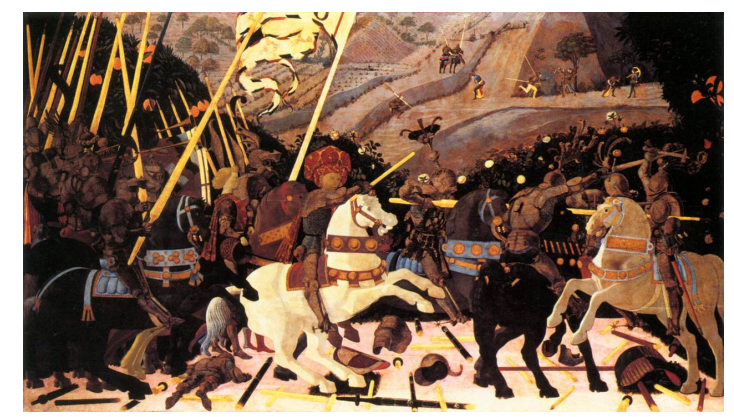

Görsel 4. Paola Uccello, 1432, San Romano Savaşı / Battle of San Romano 
Brunelleschi'nin sanatçı arkadaşları sanatın yeniden dirilişini destekleyerek doğa gözlemine, bilime ve antike'nin kalıntılarına yöneldiler (Gombrich, 2004, s. 235). Bu bağlamda Masaccio'nun çalışmalarıyla başlayan dönem, iki yüzyıl boyunca muazzam bir yenilik ve işbirliği dönemi olarak ustadan çırağa aktarılan fikirler ve teknikler ile deneme ve yanılmanın uzun süreci oldu (Labno, 2008, s. 7). Bundan dolayıdır ki, bilim ve sanat bilgisi uzun bir süre İtalyan Rönesans sanatçılarının mülkiyetinde kaldı (Gombrich, 2004, s. 235). Labno'nun (2008, s. 14-17) deyimiyle sanatta devrim niteliğindeki bu durum sonucunda getirilen kurallar, gelecek 450 yıl boyunca Batı resim sanatının başat geleneği olarak varllğgını sürdürecekti.

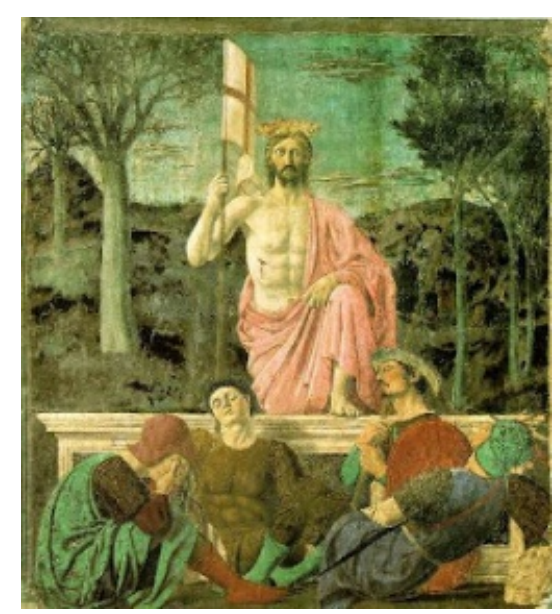

Görsel 5. Piero Della Francesca, 1460, İsa'nın Dirilişi / The Resurrection

Diğer taraftan bu tarihlerde bir önemli gelişme de resmin biçim kurgusunda oldu. 15. yüzyılın ikinci yarısından itibaren öne çıkan sanatçılar, Rönesans'ın klasik üçgen kompozisyon kurgusunu 'Piramidal' bir yapıya dönüştürerek, resimde figürler ve mekân arasında oluşan espas ilişkilerini güçlendirmiş, derinliğin artmasında etkili olmuşlardı (Varlık Şentürk, 2012, s. 80). Böylece Rönesans resminde güçlü bir konumda bulunan üçgen kompozisyon kurgusundan 'piramidal' yapıya evirilmiş oldu.

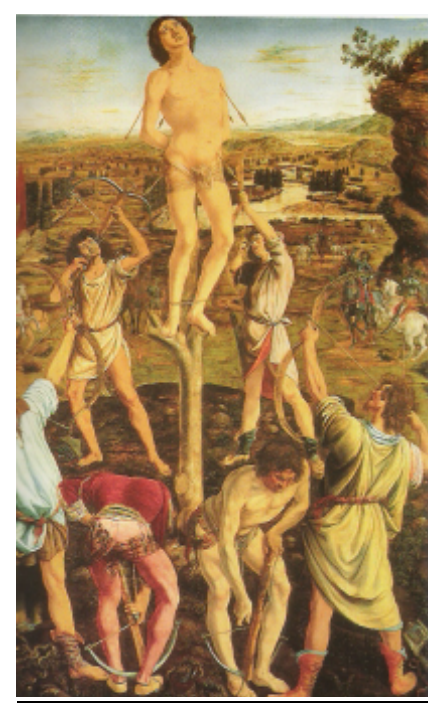

Görsel 6. Antonio Del Pollaiuolo, 1475, “Aziz Sebastianus”un Şehit Edilişi / Martyrdom of Saint Sebastian

Piero Della Francesca tarafindan yapılan “İsa’nın Diriliş̧” adlı duvar resminde (Görsel 5) kompozisyon piramidaldir (Labno, 2008, s. 39-41). Bu tür bir piramidal yapıyı Antonio Del Pollaiuolo'nun “Aziz Sebastianus'un şehit edilişi”" adlı resminde de görüyoruz (Görsel 6). 
Antonio Pallaiuolo "Aziz Sebastianus"un şehit edilişi adlı resminde figürler piramidal yapı içine yerleştirilmiştir. Gombrich (2004, s. 262) ressam Antonio Pallaiuolo'nun (1432-1498) bu eserde tüm figürleri dar açılı bir üçgen içine yerleştirerek, kompozisyonda piramidal yapı içinde resmin etkisi güçlendirmeye çalıştığından söz eder.

Kompozisyon açısından resimde bu tür gelişmeler olurken, izleyen dönemde figür bağlamında ressam Leonardo da Vinci bazı deneme ve araştırmalara girişmişti. Gombrich'e (2004, s. 302) göre, XV. yüzyıl ressamlar eserlerinde figürlerin resimden çok heykelimsi yapılara benzer katılığından kurtulmayı Leonardo da Vinci'nin boyama tekniği olan “sfumato”ya borçludur.

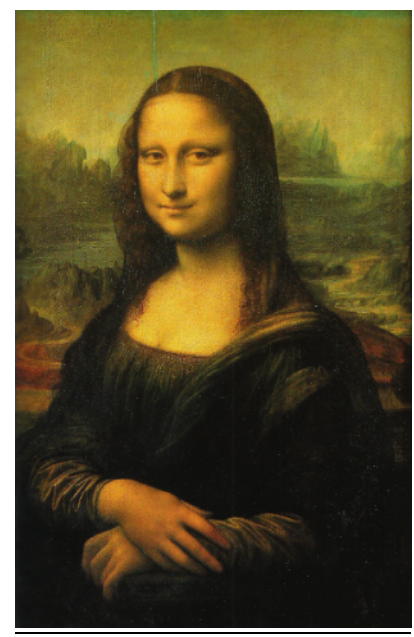

Görsel 7. Leonardo da Vinci, 1503, Mona Lisa / Mona Lisa

Leonardo da Vinci (Ö. 1519) 1şığın nesneler üzerine düşmesiyle oluşan gölge etkisini araştırmış ve nasıl sonuçlandığını bulmuştu. Da Vinci'nin çalışmalarını bu kadar büyüleyici ve gizemli kılan da hale hazırda resimdeki figürün bulanık dış hatları ve tonlamasıdır (Labno, 2008, s. 73). 'Sfumato' tekniğinde figürlerin dış hatları çok katı çizilmeyecek, böylece dış hatlar gölgede kayboluyormuş gibi belirsiz bırakıldığında her türlü sert geçiş de önlenmiş olacaktı (Gombrich, 2004, s. 302). (Bkz: Görsel 7).

Diğer taraftan yine bu dönemde, resimdeki piramidal yapıda da bazı arayışlar söz konusu olmuştur. Rönesans dönem resimlerinde, figürde ve kompozisyonda gözlemlenen değişime rağmen, bazı eserlerde bu arayışın izlerini görmekteyiz. Örneğin figür açısından, Labno'ya (2008, s. 109) göre, Tiziano'nun (1485-1576) 'Meryem'in Göğe Yükselişi' adlı eserin (Görsel 8) Meryem figüründe yeterli derecede perspektif kısaltım uygulanmamıştır.

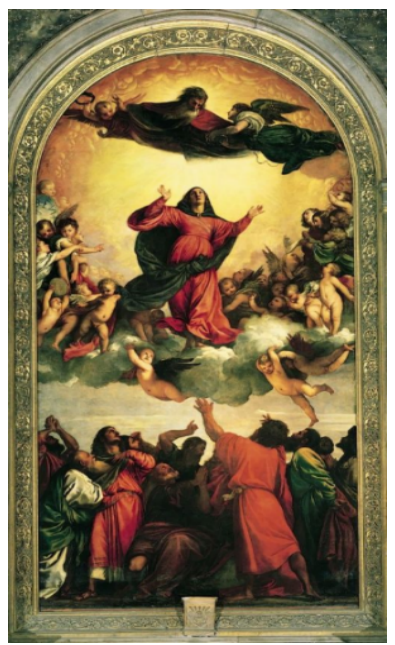

Görsel 8. Tiziano Vecellio, 1516-18, Meryem 'in Göğe Yükselişi / Pala Dell Assunta 
Oysa bu resimde piramidal yapı eserin merkezinde yer alan figür grubunu içindedir ve ana figür olan 'Meryem Ana' piramidin tepe noktasını oluştururken sağ ve sol figürlerle birlikte piramidal yapı tamamlanmaktadır (Varlık Şentürk, 2012, s. 82-83). Buna rağmen, figürde perspektifin yeterli derecede uygulanmamış olması, ressamın yeni arayışlar peşinde olduğunun bir göstergesi olarak değerlendirilebilir. Rönesans dönemi bir nevi araştırma, deneme ve yeniliklerin peşinde koşma çağıydı. Tiziano'nun bu eseri, belki de resim sanatı açısından yeni arayışlar adına tarihsel gelişimde önemli çabalardan biri olarak değerlendirilebilir.

$\mathrm{Bu}$ durumu destekler biçimde, yeni arayışların Tiziano'nun bilinçli bir seçimi olduğuna kuşku bırakmayacak biçimde, ressamın yeni denemelerinin izleri 'Azizlerle Meryem' adlı eserinde de kendini göstermiştir. Tiziano, 'Azizlerle Meryem' adlı resminde (Görsel 9) kompozisyon açısından o zamana değin görülmeyen bir değişiklik yaptı. Gombrich'e (2004, s. 331-332) göre bu durum, Tiziano'nun 'Meryem' figürünü tablo merkezinden sağa kaydırmasıyla gerçeklești. Böylece merkezi kompozisyon diyagonal yapıya dönüştü. Resim sanatında o zamana değin görülmedik bir girişimdi bu. Tiziano resmin ana figüründe alışılmamış bu uygulamayla eserde bütünün uyumu ile dengeli bir şekilde resmi daha ilginç ve canlı kılmış oldu.

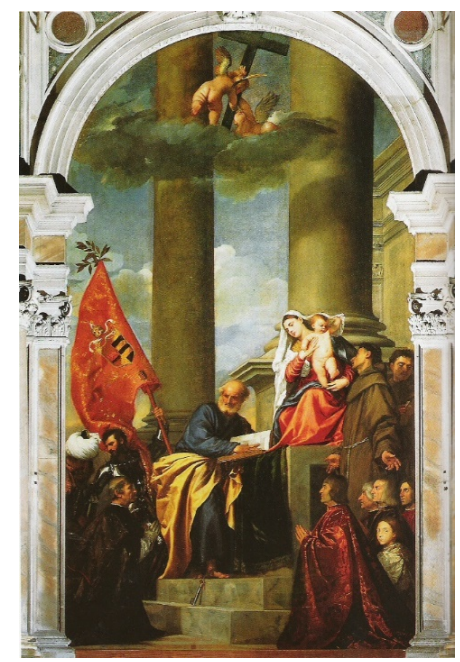

Görsel 9. Tiziano Vecellio, 1519-1526, Azizlerle Meryem (Pesaro Madonnas1) / Pala Pesaro

Resim sanatındaki bu arayış ve denemeler, XVI. yüzyılın sonlarında figürde bazı değişmelere yol açtı. Örneğin bu dönem resminde figürün normalden fazla uzun çizildiğine tanık oluyoruz.

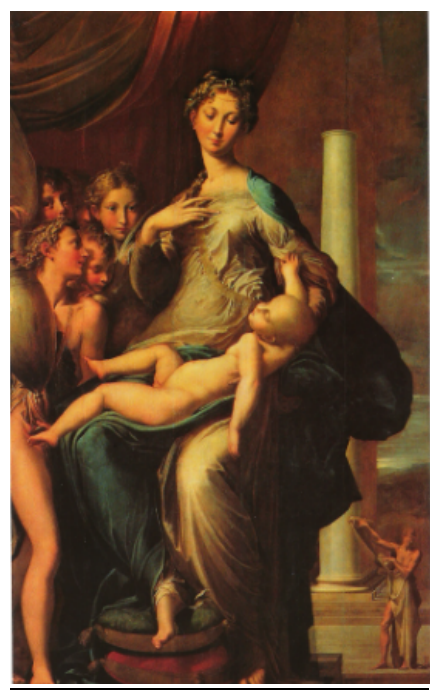

Görsel 10. Francesco Parmigianino, 1534-40, Uzun boyunlu Meryem / Madonna with long neck 
Parmigianino'nun 'Uzun boyunlu Meryem' (1534-1540) adlı tablosundaki (Görsel 10) Meryem figürünün uzuvlarında bu uzamayı görebiliyoruz. Ressam bu resimde bilerek kompozisyondaki geleneksel uyumu, yani resimde ana figür (Meryem) dışındaki figürleri, ana figürün her iki yanına eşit biçimde dağıtacak yerde, resmin sadece bir köşesine sıkıştırmıştır. Böylece ressam, geleneksel çözümlerin tek çözüm olmadığını göstermiş oldu. Bundan dolayı, Parmigianino ile birlikte o çağın tüm ressamları yeni ve beklenmedik bir şey yaratmaya bilinçli yönelimleriyle belki de ilk modern ressam oldular (Gombrich, 2004, s. 367).

Yine aynı dönem içinde, Avrupa'nın güneyinden kuzeyine doğru gittiğimizde, resmin kompozisyonunda, Bruegel'in 'Köy düğünü' adlı tablosunda (Görsel 11) olduğu gibi, ana figürün konumunun resim içinde köklü bir değişime uğradığına tanık oluyoruz.

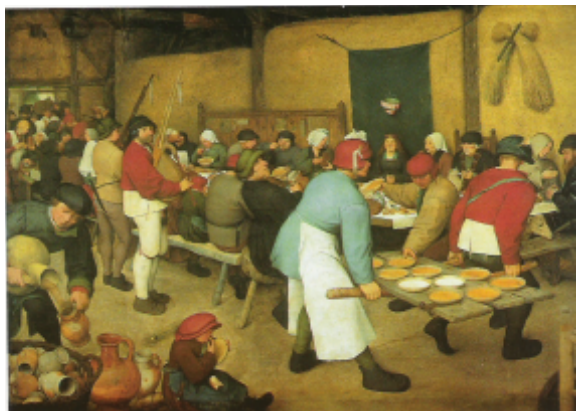

Görsel 11. Pieter Bruegel, 1567, Köy düğ̈̈nü / Peasant Wedding

Pieter Bruegel'in (1525-1569) 'Köy düğünü' adlı bu eserinde bir tahıl ambarında verilen düğün ziyafetini görüyoruz (Gombrich, 2004, s. 382-383). Resme biraz dikkatlice baktığımızda resim konusunu oluşturan ana figür olan "gelin"in resimdeki boyutunun küçüldüğüne tanık oluyoruz. $\mathrm{Bu}$ durum Ortaçağdan 1567 yılına değin uzunca bir süredir Bat1 resim geleneğinde ana figür açısından görülmemiş bir değişim olarak kayda değerdir. Gombrich (2004, s. 383); "Bruegel kendinden sonra gelen Flaman ressam kuşaklarına sanatta yeni alan kazandırdı" derken bu durumu işaret ediyor olsa gerektir.

Bruegel'in bu resminden yaklaşık 40 yıl sonra, Avrupa'nın güneyinde de resim sanatında figür açısından bazı değişimler söz konusudur. Gombrich'in (2004, s. 373) belirttiği gibi, El Greco'nun alış1mışın dışında resimde figür ögesinde uzun figür tarzını benimsemiş olduğunu görüyoruz (Görsel 12). El Greco, 'Beşinci Mührün Aç1lışı' adlı bu eserde Parmigianino'nun ‘Uzun boyunlu Meryem' adlı eserinde olduğu gibi 'Meryem' figüründe sergilediği uzamayı, bu kez resmin tüm figürlerine yaymış görünüyor. Bu açıdan bakıldığında, El Greco'nun resimde figürsel değişimi biraz daha ileri bir evreye taşıdığını söyleyebiliriz.

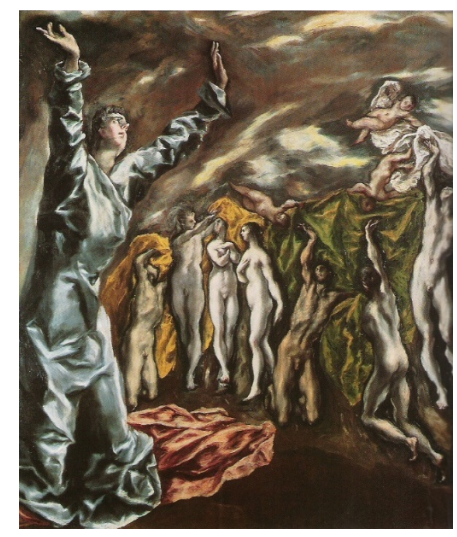

Görsel 12. El Greco (Domenikos Theotokopoulos), 1608-14 dolayları, Beşinci Mührün Aç1lış1 / The Opening of the Fifth Seal (The Vision of St John) 
XVII. yüzyılda ise, Caravaggio'nun resimde alışıldık yöntemlerin dışında sanatı yeni bir bakış açısıyla ele almak istediğine tanık oluyoruz (Gombrich, 2004, s. 392). Bu bağlamda, Caravaggio resim sanatını Rönesans'ın üçgen kompozisyonları yerine diyagonal ve dağınık düzenlemelerle oluşan açık kompozisyonlara dönüştürdüğünü (Görsel 13) görüyoruz (Varlık Şentürk, 2012, s. 129).

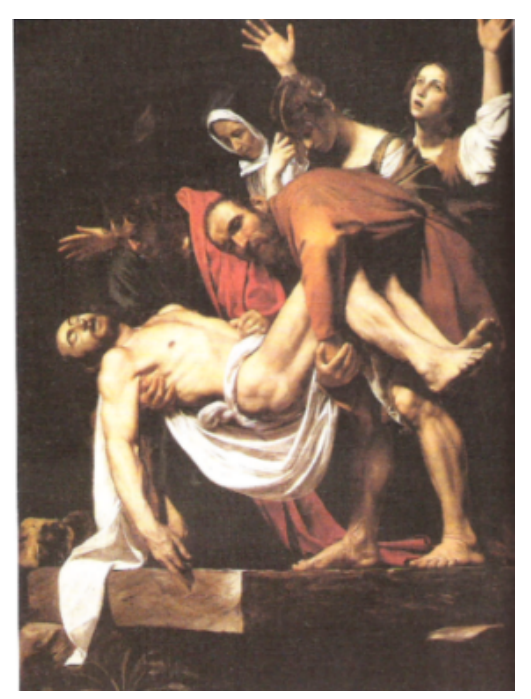

Görsel 13. Michelangelo Merisi da Caravaggio, 1602-1603, "İsa'nın Mezara İndirilişi / The Entombment of Christ

Sanatta XVII. yüzyıl Barok dönem itibariyle ihtişamın yanında, duyusal zenginlik, canlılık, hareket, gerginlik ve duygusal coşkunluk eğilimi olduğundan (Baroque art and architecture, t.y.), Caravaggio'nun resimlerinde bu eğilimlerden en çok kompozisyonda hareketin yakalanmasıyla birlikte etkilendiğini gözlemliyoruz (Sunal, 2016). Bu yüzyılda Caravaggio ile birlikte tarihsel gelişim açısından resmin kompozisyonunda üçgen yapıdan pramidal yapıya ve buradan da diyagonal yapıya açık kompozisyonla evirilmiş olduğunu görüyoruz. Bu diyagonal yapı ve açık kompozisyon figürde dağınık düzenlemelerin yolunu açmıştır. Bu durum resimde figür ve kompozisyon açısından yeni bir aşama olarak değerlendirilmelidir. Bu dönemin, Rönesans'tan bu yana resim sanatında yaklaşık iki yüz yıldan sonra gelinen bir aşama, figür ve kompozisyon açısından köklü değişimleri içeren bir evre olduğunu söyleyebiliriz.

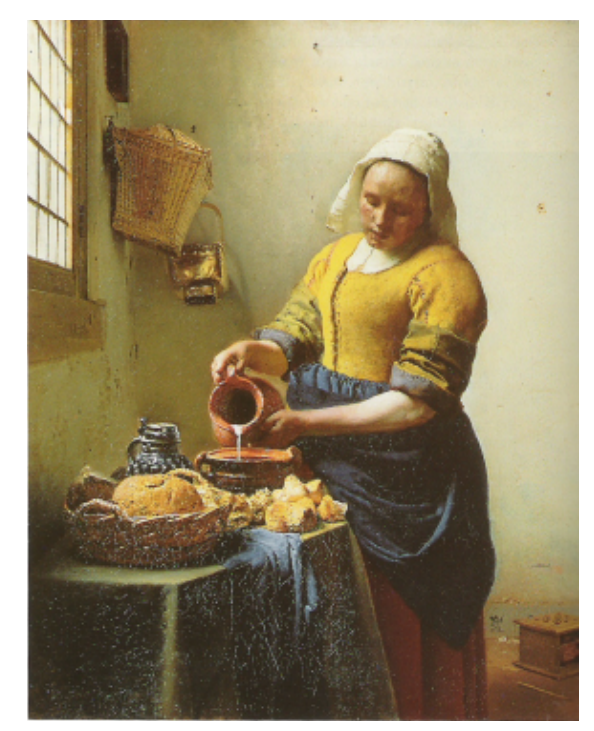

Görsel 14. Jan Vermeer, 1658, Süt Döken kadın / The Milkmaid 
Diğer taraftan resimde önemli bir değişiklik de Gombrich'e (2004, s. 430) göre, resimde konu açısından ortaya çıkmıştır. XVII. yüzyıl sanatçıları önemli bir konu olmadan da güzel bir resim yapılabileceğinden yola çıkarak, resimde konunun ikinci dereceden önemli olduğunu savundular. Ressam Jan Vermeer günlük yaşamı kendi akışında resmederek (Görsel 14), resimde bu tür bir yaşamı mizahi ve alaycı bir konumdan kurtarmıştır. Böylece, Avrupa'nın kuzeyinden Hollandalı ressam Jan Vermeer ile birlikte resimde figür bağlamında konu odaklı önemli bir değişime tanık olduğumuzu söyleyebiliriz. Bu durum yine Kuzey Avrupalı bir ressam olan Flaman Jean-Antoine Watteau (1684-1721) tarafindan devam ettirilmiş, resimde figürün sıradanlaşmasına dair sanat anlayışı Kuzey Avrupalı ressamlar tarafından pekiştirilmiştir (Görsel 15).

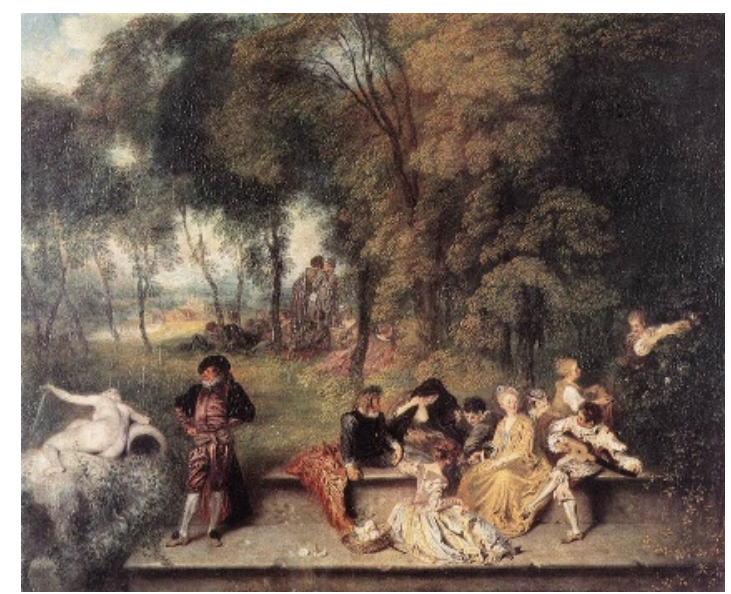

Görsel 15. Jean-Antoine Watteau, 1716-19 dolayları, Açık havada eğlence / Merry company in the open air

Rokoko adı verilen sanat akımının öncülerinden olan Jean-Antoine Watteau (Rococo Art Style, t.y.), XVIII. Yüzyıl başlarında Fransız aristokrasisinin yaşayış zevklerini belli bir incelikte tuvale yansıttı (Gombrich, 2004, s. 454-455). Ressam Watteau, genellikle saraya yakın sıradan günlük yaşam sahneleri, sosyal yaşamı yoğun ve abartılı bir biçimde resmetmiştir (Varlık Şentürk, 2012, s. 157-158).

1760'lara gelindiğinde ise, resim sanatında antikçağa artan ilgi nedeniyle figür açısından yeniden eski konuma bir dönüş gözlemliyoruz. Belki bu eskiye özlemde, yeni arayışlardan yorulan sanatçının o dönemde yeni yeni yapılan arkeolojik kazılarda ortaya çıkan antik çağa ait sanat eserlerde gözlemlenen ideal estetik biçemine olan hayranlığın da etkisi olabilir.

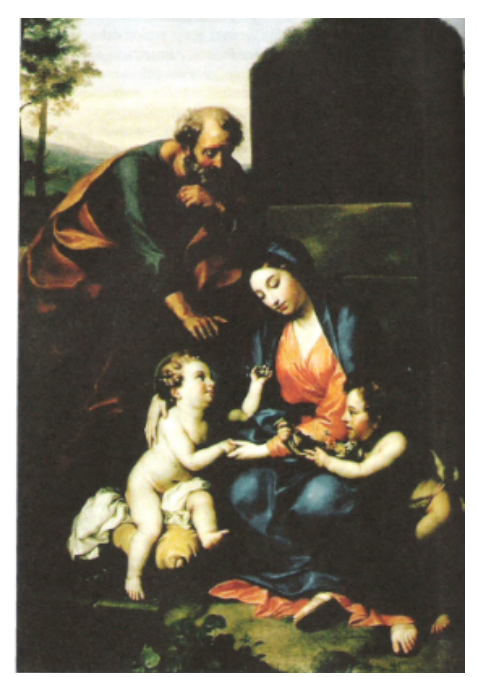

Görsel 16. Anton Raphael Mengs, 1763, Kutsal Aile / The Holy Family with the Infant St John the Baptist 
Neoklasizm (Neoakademizm, 1760-1820) olarak adlandırılan bu dönemde, Yunan ve Roma sanatının güzellik anlayışının yeniden canlandırılarak, Antik Yunan düşünce sistemi ve estetiğine geri dönülmesi gerektiği savunulmuştur. Böylelikle, Yunan sanatının ideal güzellik anlayışını belirleyen çizgisel yapı, kapalı form ve denge prensibi resimde yeniden merkeze alınmıştır (Varlık Şentürk, 2012, s. 168). Bu duruma örnek olarak; Anton Raphael Mengs'in 'Kutsal Aile' adlı resmi gösterilebilir (Görsel 16).

Rönesans resim sanatı örnekleri arasında sıklıkla rastlanan bir konu olan 'Kutsal Aile' betimlemesinde ressam Mengs, figürlere yüklediği ideal güzellik anlayışı ile Meryem, çocuk İsa ve melek figürünün duruşlarını üçgen kurgu içinde yapılandırıyordu (Varlık Şentürk, 2012, s. 171). Böylece resimde figür ile birlikte kompozisyon ögesinde yeniden piramidal yapıya dönülerek, resimde kompozisyonun önem kazandığı bir döneme tanıklık etmiş oluyoruz. Buraya kadar tarihsel süreçte resim sanatı, figür ve kompozisyon bağlamında, gelişim açısından ara ara geriye dönüşler yaşasa da ileriye doğru farklı değişimler için bir nevi güç topladığını söylemek mümkündür. Çünkü 1842 yılına geldiğimizde ressam Constable'ın geçmiş ustaların eserlerine hayran olmakla birlikte, "kendi gözleriyle gördüğ̈̈" şeyi çizmek, önceden planlanmış kompozisyon, renk gibi yöntemleri tümüyle yadsımak isteğine tanık oluyoruz (Gombrich, 2004, s. 493-495).

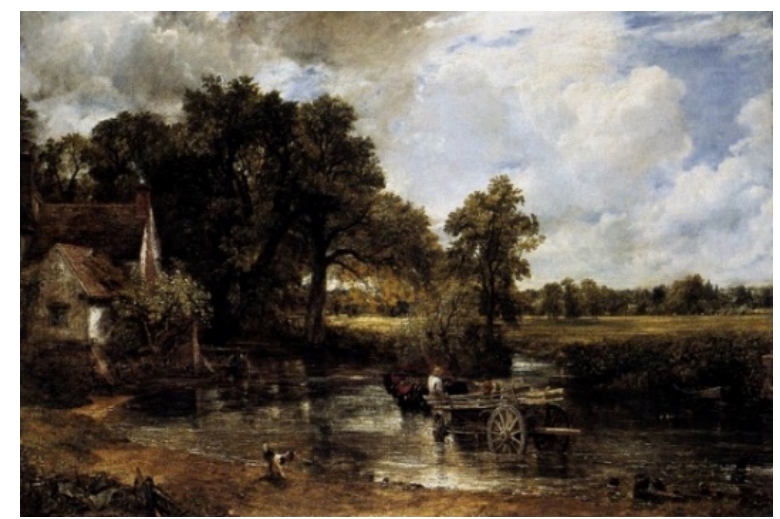

Görsel 17. John Constable, 1821, Saman arabası / The Hay Wain

Bu tavrın sonucunu, Constable'ın 1821 yılında yaptığı "Saman arabası" adlı resimde (Görsel 17) görebiliyoruz. $\mathrm{Bu}$ resimde öncelikle göze çarpan unsur, figürün resimde hem var olması hem de olmaması durumudur. Figürün silikleştiği, ama yok olmadığı bu durumun, 1854 yılına geldiğimizde biraz daha figüre doğru evirildiğine tanık olacağız.

Nihayet, Gustave Courbet akademinin kurallarını bir tarafa bırakarak, kendisini sirtında resim malzemeleriyle kırda yürürken resmetmesiyle (Gombrich, 2004, s. 511) birlikte figüre doğru bir evirilme de başlamış oldu (Görsel 18).

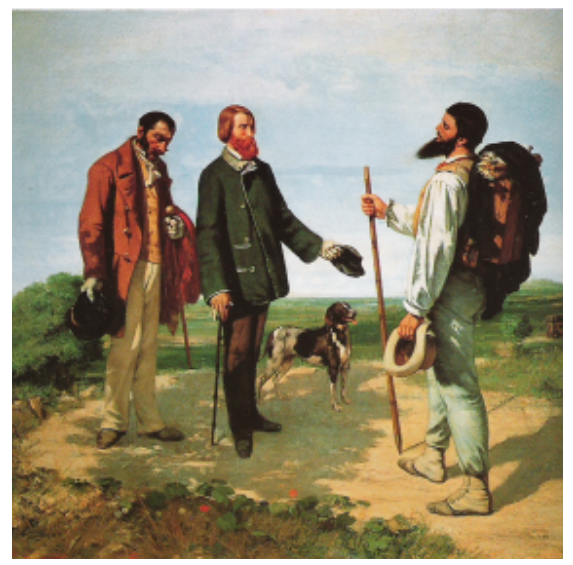

Görsel 18. Gustave Courbet, 1854, Günaydın Bay Courbet / Bonjour Monsieur Courbet 
Diğer taraftan aynı dönemde, Jean-François Millet tarlada çalışan köylüleri çizdi (Görsel 19). Ressamın 'Başak toplayan kadınlar' adlı resminde ne dramatik ne de komik bir öykü betimleniyor. Bu resimde söz konusu olan sadece başak toplayan köylü kadınlardır: İște bu bir devrimdi (Gombrich, 2004, s. 508). Böylece resimde başat unsur figür anlayışına yeniden sağlam bir dönüş yapıldığını, ancak bu kez figürlerin sıradan insanlar olduğunu görüyoruz.

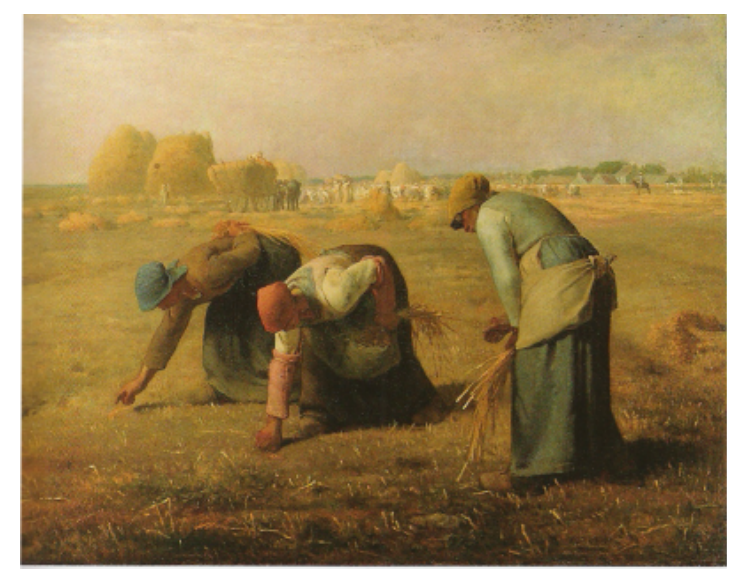

\section{Görsel 19. Jean-François Millet, 1857, Başak Toplayan Kadınlar / The Gleaners}

1800'lü yılların sonuna geldiğimizde ise, Edouard Manet (1832-1883) ve arkadaşlarının, 'eğer nesnelerin nasıl görünmesi gerektiği değil de kendi gözlerimizle bakarsak neler keşfedebiliriz' ilkesine dayalı olarak resimler yapmaya başladığını gözlemliyoruz. Bu anlayışla Manet ve arkadaşları, resimde betimlenen nesnelerin doğa içinde kendi renkleriyle zenginliğini keşfederek, resmi daha ileri bir evreye taşımış oldular (Newall, 2008, s. 6). Kendilerine Empresyonistler denen bu ressamlar, doğaya baktığımızda her nesnenin birçok renk tonundan oluştuğunu gördüler (Gombrich, 2004, s. 514). Böylece resimde empresyonistlerin modern konuları yeni stil ve tekniklerle başarıyla yansıtmaları, bu grup sanatçıları takip edecek gelecek nesil ressamlarda soyut anlatımda üst düzey başarıyı elde etmek için ilham kaynağı oldu (Newall, 2008, s. 6).

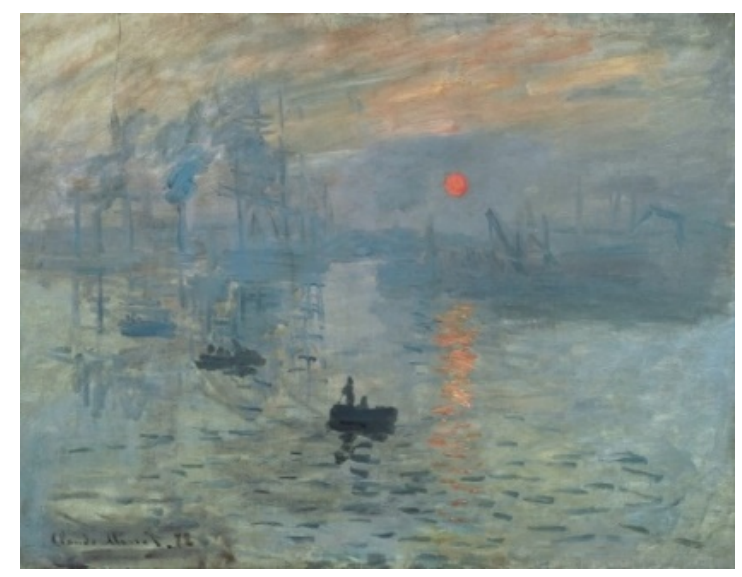

Görsel 20. Claude Monet, 1874, İzlenim / Impression Sunrise

Resimde Empresyonist tekniğin elde edilmesi için doğada konu, 1şık ve buna bağlı rengin sürekli değişim hali, yani ressamın an '1 yakalaması, ancak hızlı vuruşlar ile boyama ve ayrıntıdan çok resmin genelinin etkisine dikkat etmesiyle mümkün olacaktı (Gombrich, 2004, s. 518). Böylece, resimde figür ve kompozisyon ögelerinin yanında resim yapma tekniğinin de değiştiğini ve bu tekniğin önem kazanarak ön plana çıktığını görüyoruz. Bu durum, Leonardo da Vinci'nin resim yapmada geliştirdiği çok önemli bir boyama tekniği olan 'sfumato' tekniğinin değişimi demekti. Böylece resimde figür ve 
kompozisyon ögelerindeki değişimin, resim yapma tekniğini de değişime sürüklediği bir evreye girdiğine tanık oluyoruz.

Claude Monet'in 'izlenim' adlı eseri (Görsel 20), biçimsel olarak çağdaş bir endüstriyel konuyu yakalamasıyla kendi zamanı için oldukça yenilikçiydi (Newall, 2008, s. 15). Bu resim, figürün sıradanlaşması açısından Jean-François Millet'in 'Başak toplayan kadınlar' adlı resminden sonra, kompozisyonun sıradanlaşması ile bir önceki sürecin devamı olduğu söylenebilir. Resim sanatındaki bu durum Paul Cezanne (1839-1906) tarafindan devam ettirilmiştir.

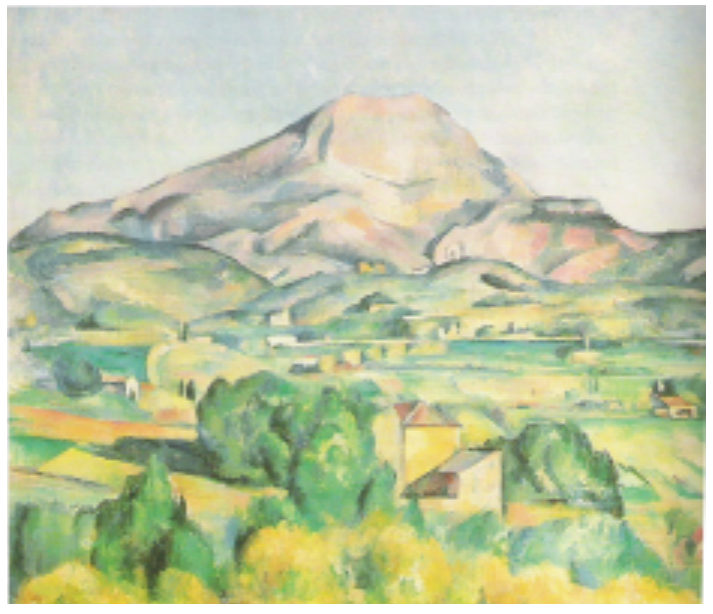

\section{Görsel 21. Paul Cezanne, 1885 dolaylarl, Sainte-Victoire dağının Bellevue'den görünüşü / Montagne Sainte-Victoire}

Paul Cezanne (1839-1906) nesnelerin yüzeyi, fizikselliği ve üç boyutluluğuyla ilgilenmiş (Newall, 2008, s. 116), geleneksel resim tekniklerini bırakmış, işe sıfırdan başlamıştır (Gombrich, 2004, s. 544). Ressam Cezanne daha çok hacim ve derinlik duygusuyla ilgilenmiş ve bunu geleneksele bağlı kalmadan yapılabileceğini keşfetmiştir (Görsel 21). Cezanne, 'doğru çizim'e karşı bu ilgisizliğinin sanat tarihinde bir depremi harekete geçireceğinin farkında olmadan (Gombrich, 2004, s. 544), önemli bir değişime imza atmıştır. Empresyonistler sergiledikleri bu tavırla resimde konu, figür, kompozisyon ve teknik bağlamda gelenekten tam anlamıyla kopuşu gerçekleştirmişler, gerektiğinde eski kazanımları yadsıyarak 'yeninin keşfi'ne olanak tanınabileceğini de göstermişlerdir. Empresyonizm döneminde resim sanatının bu yeni ve farklı olanın peşinden ısrarlı gidişinde, hiç kuşkusuz, fotoğraf makinesinin keşfinin (ve kullanımına başlanmasının) önemli bir payı vardır. Klasik resimlerin verdiği görselliği fotoğraf kartlarına sı̆gdıran bu yeni buluş, bir nevi resim sanatına ve ressamlara meydan okumuş, empresyonistler sayesinde bu meydan okumaya sanatsal bir karşılık verilmiştir. Böylece resim sanatının ilk ciddi büyük bunalımını Empresyonist ressamlar, ortaya koydukları çeşitli uygulamalarla, üç yüz yıllık 'sfumato' tekniğini değiştirerek savuşturdukları söylenebilir. Resim sanatındaki bu büyük bunalımın, Empresyonistlerden sonraki kuşak sanatçılarına da miras kalan zorlu bir alan olduğunu, onların resimlerine baktığımızda daha iyi anlıyoruz. O ressamlardan biri olan Vincent Van Gogh, resimde yaşanan sorunların üzerine gitmiş ve bu nedenle belki de çağının en önemli ressamlarından biri olarak tarih sahnesine çıkmıştır.

Van Gogh, resimde nesnelerin görünüşünü abartmaktan ve değiştirmekten hiç çekinmedi. Böylece, farklı yoldan da olsa, Cezanne'ın vardığı noktaya geldi (Gombrich, 2004, s. 548), yani resimde figürün sıradanlaşmasından ötürü deformasyon aşaması (Görsel 22). 


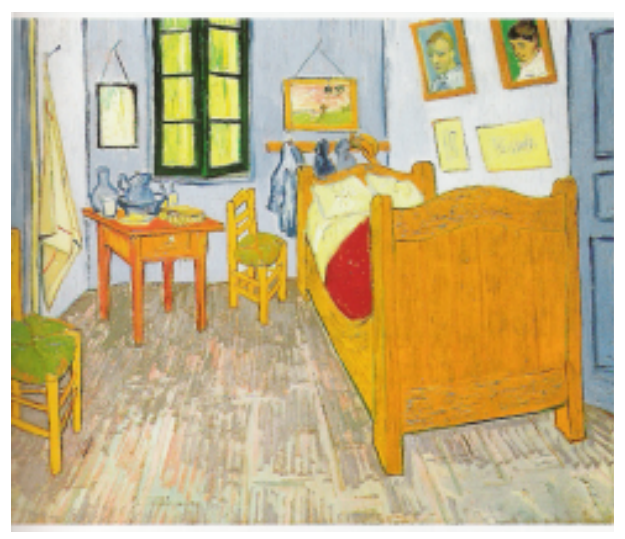

Görsel 22. Vincent Van Gogh, 1889, Sanatçının Arles'daki odası / The Bedroom

Ekspresyonistler kendilerini duygulandıran an'ları figür ve kompozisyona bağl1 kalmadan resmetmeye çalıştılar. Böylelikle resimde figür ve kompozisyonun sıradanlığı, ancak ilettiği duygu ile biricikliğe evirilmesi söz konusu olabilmiştir. Bunun sonucunda resimde figür ve kompozisyonun Empresyonistlerce ikinci plana çekilmesi durumu, ekspresyonistler tarafından ilettiği duygu oranınca zaman zaman birinci plana tekrar getirildiği söylenebilir.

XIX. yüzyılın başkaldıran sanatçıları tarafından resimde betimlemede gelenekten kopuş (Gombrich, 2004, s. 561) ve eski anlayışındaki figür ve kompozisyonun değişmesi sonucu, resim sanatında yeni deneyimlere de kapı aralanmış oldu. İşte Picasso tam da böyle bir dönemde resim sanatında doğru yerde ve doğru zamanda yeni denemelere girişti.

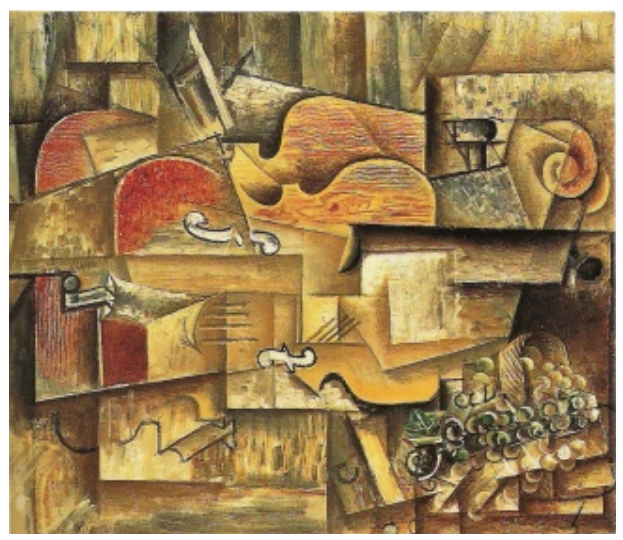

Görsel 23. Pablo Picasso, 1912, Keman ve üzümler / Violin and Grapes.

Paris'te o yıllar (1900'ler) resimde çok daha köklü bir kopuş olan Kübizm doğmuş ve resimde figürü tümden kaldırmayı değil onu yeniden düzenlemeyi amaçlamıştı (Gombrich, 2004, s. 570). Böylece resimde geleneksel biçimlere 1şık ve gölge kullanarak hacim verme işlemi bir tarafa bırakıldı (Gombrich, 2004, s. 571). Bu durumun sonucunda bir kez daha Leanardo da Vinci ustanın önemli boyama tekniği olan sfumato'nun Empresyonistlerden sonra Kübistler tarafından da yadsınmış olduğunu görüyoruz. Kübistlerin resimdeki değişime boyama tekniğinden başlamalarının nedeni ise resim sanatında figürün yeniden inşasından başka bir şey değildi. Böylece Picasso'yu Cezanne'a götüren süreç başlamış oldu.

Picasso, Cezanne'ın; 'doğayı küreler, koniler ve silindirlerden oluştuğu ilkesi’ne sıkı sıkı sarılarak, figürleri doğada göründükleri gibi veya izlenimlerini vermekten çok üç boyutlu ve kalıcı şekilde vermeyi düşündü. Örneğin bir kemanın hayalimizde oluşan görüntüsünü gerçek görüntüsünden çok farklı olduğunu kabul ederek, kemanın hayalimizdeki görüntüsünü vermeye çalıştı. Sonuç; 'Keman ve üzümler' adlı eserinde (Görsel 23) olduğu gibidir (Gombrich, 2004, s. 574). Picasso böylece Kübizm 
ile birlikte figürün resimdeki önemini bir kez daha birincil konuma yükseltmiş, ancak figür açısından bu birincil konum Rönesanstan bu yana biçim olarak epeyce değişmiştir.

Norveçli ressam Edward Munch ile resimde figür üzerine bu değişim, arayış ve araştırmalar devam etmiştir. Araştıran sanatçılar arasında yer alan Munch (1863-1944) 'Çığlık' adını verdiği taş baskı eserinde (Görsel 24) ani bir duygunun duyusal izlenimimizi nasıl değiştirebileceğini anlatmaya çalışırken, çığlık atan yüzü (figür) deforme etmiştir (Gombrich, 2004, s. 564).

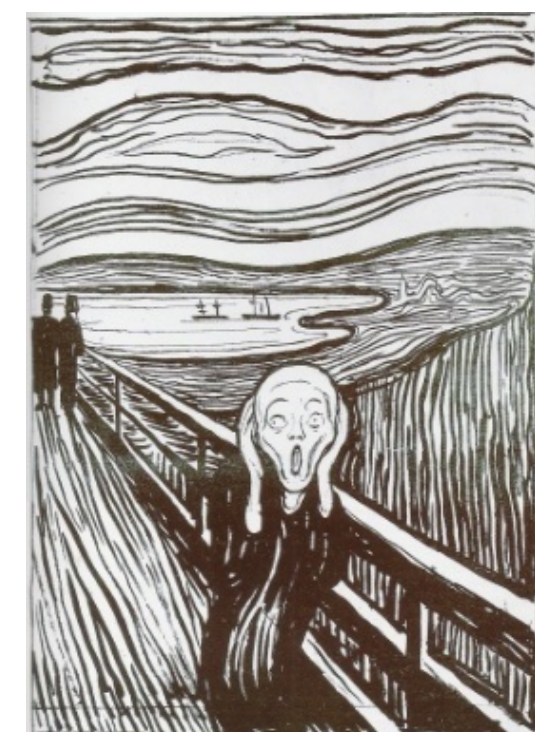

Görsel 24. Edward Munch, 1895, Çı̆̆lık/Skrik

Rönesans'ın ideal yüzünü temsil eden Mona Lisa'dan Munch'un Çı̆̆lık atan yüzüne doğru resimde figürün biçim olarak değişimi oldukça çarpıcı olduğunu söylemek zorundayız. Tabii ki etkileyici olan nokta resim sanatında figürün geçirdiği gelişim ile birlikte köklü değişimidir. Bu nedenle Munch'un Çığlık’ aynı zamanda resim sanatının figür bağlamında geldiği değişimin çığlığı olduğu söylenebilir. Bu durumun geri dönülemez bir aşama olduğunu, ancak izleyen yıllarda ressamların eserlerinde görülen figürlerde tanık olacağız aynı Kandinsky'nin eserlerinde olduğu gibi.

Vassily Kandinsky resimde figürün biçim olarak değişimini daha ileri bir evreye götürmüş ve tamamen soyutlamıştır. Kandinsky resimde konu olmadan sadece ton ve biçim etkilerine dayanarak duygularını ifade etmiş (Gombrich, 2004, s. 564) ve böylece 'Soyut Sanat' olarak adlandırılan akımı da başlatmıştır (Gombrich, 2004, s. 570).

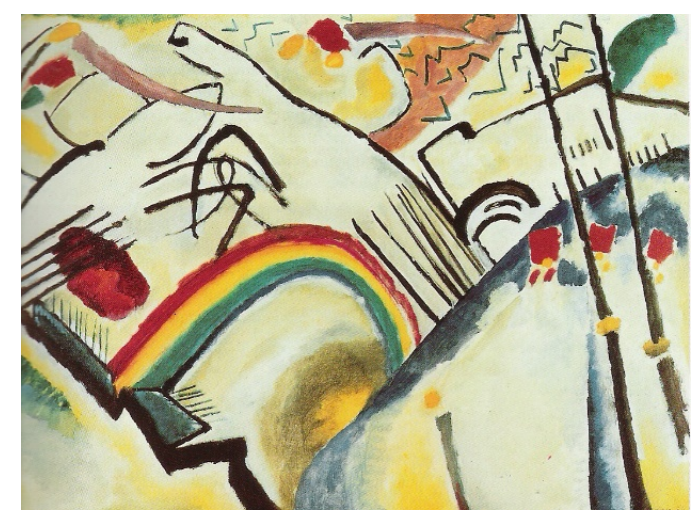

Görsel 25. Vassily Kandinsky, 1910-11, Kazaklar / Cossacks 
Picasso resimde figürün biçimiyle oynasa da figüre birincil önem vermişti. Oysa Kandinsky bir kez daha figürü ikincil bir konuma indirgemiş, hatta bir adım ileriye giderek, resimde geleneksel anlamdaki figürü yok saymıştır. $\mathrm{Bu}$ anlayışla Kandinsky'nin resminde kompozisyonun salt soyut biçimlerin kendi aralarındaki ilişkilerine, yani sanat eleman ve ilkelerine göre düzenlendiğine tanık oluyoruz (Görsel 25). Resim sanatındaki bu durum Kandinsky'nin çağdaşı Piet Mondrian tarafindan da sürdürülmüştür (Görsel 26).

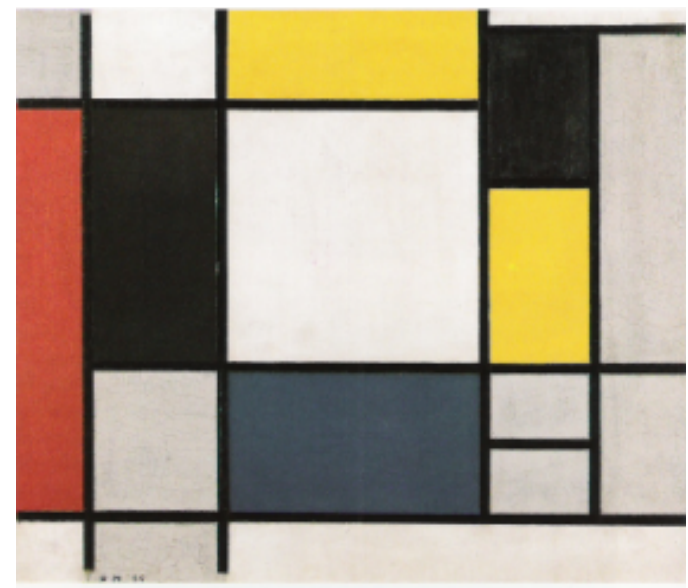

Görsel 26. Piet Modrian, 1920, Kırmızı, siyah, mavi, sarı ve griyle düzenleme / Composition with red, black, blue, yellow, and gray

Kandinsky ve Mondrian bize resimde konu, figür ve kompozisyon kadar biçim ve rengin de önemini hatırlatarak, Empresyonistlerin renge yaklaşımını (özellikle Kandinsky) oldukça genişlettiğini söyleyebiliriz. Bu durum Sürrealistlerle birlikte biraz değişim gösterse de resim sanatında figür ve kompozisyonun, biçim ve renk ile birlikte düşünülmesi gereğini ortaya koymuştur. Bu duruma tepki olarak, yeniden figür ve kompozisyonda arayışlar başlamışsa da Sürrealistler bu arayışı, ancak 'bilinçaltından sahneler' şeklinde öngörerek ileriye götürebilmişlerdir.

'Gerçekten çok gerçekçi bir şey yapmak' isteyen Sürrealistlerin bu isteği, Salvador Dali'nin resimlerinde olduğu gibi (Görsel 27), düşlerdeki garip karmaşayı görselleştirerek (Gombrich, 2004, s. 593) bulmaya çalışmaları, resimde figür ve kompozisyon sorunsalına gerçek dünya düzleminde bulamadıkları çözümü, düşsel dünyada aramaya girişmelerini göstermesi bakımından kayda değerdir.

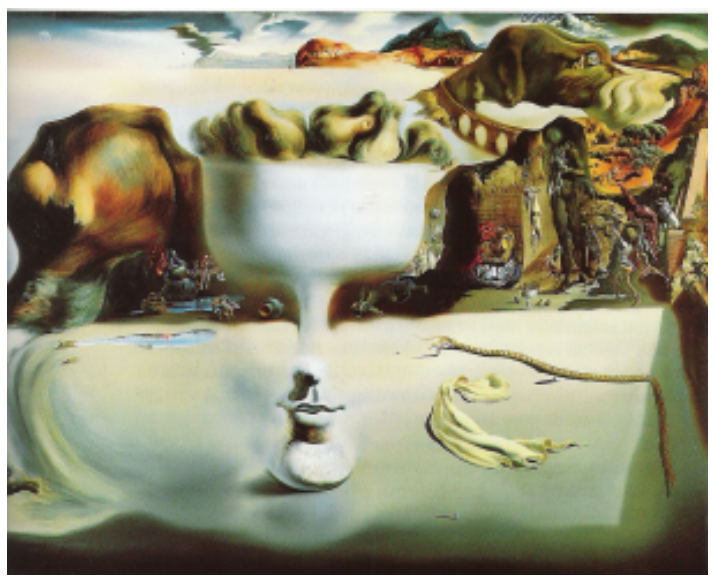

Görsel 27. Salvador Dali, 1938, Bir yüzün ve bir meyve kâsesinin kumsaldaki hayali / Apparition of face and fruit dish on a beach 
Bundan dolayı Sürrealistler, resmin figür ve kompozisyon açısından önceden planlanmasına karş1 çıktılar ve onun kendi kendini büyütmesini savundular (Gombrich, 2004, s. 592). Böylelikle resimde figürün gelişimi ve değişimi, kendi kendini var etme aşamasına evirilmiş oldu. Bu aşamada resim sanatı kendi tarihindeki ikinci büyük bunalımını yaşıyordu ki, bu bunalımın zeminini o çağda yapılan önemli bilimsel keşiflerin sonuçları oluşturuyordu. Her disiplinin kendini sorguladığı bu dönemde resim sanatının da üzerine düşen sorgulamayı yaptı̆̆ söylenebilir. Böylece Sürrealistlerle birlikte resimde figürün yeniden ön plana gelişi, insanın bilinçli halinden değil, bilinçaltından beslendiği için biraz garip, biraz düş olmakla birlikte bu durumun epeyce gerçek olduğunu söylemek zorundayız. Bu yolla Sürrealistlerin düşleri bir anlamda gerçek olmuştur diyebiliriz. Her ne kadar soyutcuların (Kandinsky ve Mondrian) biçime ve renge yönelmesiyle soyutlaşan figür, Sürrealistlerce düş yoluyla yeniden vücut bulmuş olsa da, Sürrealistlerce figürün bu yeniden biçimlendirilmesi durumu, biçimle birlikte resimdeki anlamı da kapsadığını söyleyebiliriz.

\section{Sonuç}

Rönesans’tan Sürrealizme resim sanatının tarihsel gelişimine baktığımızda, bir sanat eseri olarak resimde değişimin figür ve kompozisyon açısından biçim ve içerik bağlamında bütünleşik bir anlayışla izleyiciler için anlamlı hale gelme yolculuğunun devam ettiğini söyleyebiliriz. Bu durumun nedenini, resim sanatçısının aktarmak istediği duygu ya da düşenceyi, bir konu bağlamında figür ve kompozisyona vereceği rolde aramak gerekir. Tarihsel süreçte olaylar ve insanlar gibi sanatçıların da değişimi söz konusu olduğundan, resim sanatında figür ve kompozisyon bağlamındaki değişimin devamını bekleyebiliriz. Giotto'nun 1300'lü yıllardan itibaren resimde perspektif kısaltım tekniğini uygulamasıyla birlikte resim sanatında figür ögesinde başlattığı değişim bir çı̆̆ gibi büyüyerek, Rönesans dönemine başlangıç oluşturmuştur. Rönesans'ta resimde görülen değişim ihtiyacı o kadar büyüktü ki, ressamlar adeta birer bilim insanı gibi tabiatta var olan olay ya da objeleri dikkatli bir gözle gözlemlemeyerek, sonuçlarını tuvallerine aktarmaya başlamışlardı. Gombrich'in (2004, s. 235) belirttiği gibi bu durum, o çağda bilinen dünyanın bilim ve sanat bilgisine sahip olma ayrıcalığını, uzunca bir süre İtalyan Rönesans sanatçılarının mülkiyetinde kalmasına neden oldu. Böylece, İtalyan Rönesans Dönemi ressamlarının resim sanatına getirdiği yenilikler, figür ve kompozisyon bağlamında, bir kural olarak Batı resim sanatında varlığını yüzyıllar boyunca sürdürdü. Özellikle, Leonardo da Vinci'nin birçok deneme ve gözlemden sonra elde ettiği çığır açan buluşu olan 'sfumato' tekniği (1500'lü yıllar), resim sanatında figür olgusunu gerçekçi biçimde tuvale yansıtmada önemli bir aşama olarak resim sanatı tarihine geçti. Sfumato tekniği, resim yapma geleneğindeki hâkimiyetini uzunca bir süre, fotoğraf makinesinin icad1 ve Empresyonizm akımının doğuşuna (1800'lü yıllar) kadar sürdürmüştür. Resimde kompozisyon ise, Rönesans'ın ilk on yıllarında görülen üçgen yapı içine yerleştirilen figürlerle sağlanan merkezi yapı ile kuruluyordu. İtalyan ressam Tiziano'nun (1485-1576) kompozisyonda yapıyı değiştirme adına denemelere giriştiğinde (Görsel 9) takvimler 1519 yılını gösteriyordu. Tiziano'nun kompozisyonda denemelere girişmesinden 15 yıl sonra bu kez Parmigianino resimde figürün yapısı üzerine bazı denemelere girişti (Görsel 10). Parmigianino resimde figürün uzuvlarında gerçek dünya ile çelişecek biçimde bir sunumla değişime imza attı. Bu dönemi izleyen yıllarda, Avrupa'nın Kuzeyinden gelen değişim rüzgârı resimde figürü başat bir konumdan sıradan bir role indirgedi, aynı Bruegel'in Köy düğünü (1567) adlı eserinde (Görsel 11) olduğu gibi. 1608 yılında bu kez El Greco resimde figür ögesinde değişimin öncüsü olmuştur (Görsel 12). XVII. Yüzyllda ise, Caravaggio kompozisyon bağlamında resimde değişime öncülük ederek eserlerinde açık kompozisyon denemelerine girişmişti (Görsel 13). Resim sanatında figür ve kompozisyon açısından bu gelişmeler olurken, XVII. yüzyıl ressamları resimde konuyu ikinci planda düşünüp, sıradan insanları resmederek, figürü ön plana çıkardılar. Kuzey Avrupalı Ressam Jan Vermeer'in bu bağlamda resimde figürü halka indirdiği söyleyebiliriz (Görsel 14). Bu durum Avrupa'da o zamanlar yeni gelişen akıl çağ1 ve Hümanizmin etkisinden bağımsız düşünemeyeceğimiz, devrim niteliğinde bir gelişmeydi. Bu nedenle, tarihsel süreçte 
ressamın yaşadığı çağa tanıklığı, tuvalinin içine nüfüz ederek, resimde figür ve kompozisyon bağlamında önemli değişiklere öncülük ettiğini söyleyebiliriz. Bu tarihsel süreç, arkeolojik kazılarda gün 1şığına çıkarılan, antik çağ sanat eserlerine duyulan hayranlıkla harmanlanarak belli bir senteze uğramıştır (Neoklasizm). Bu aşamadan sonra, 1800'lü yılların ortalarında, "kendi gözleriyle gördüğü" şeyi çizmek olgusu, hiç eskimeyecek bir biçimde resim sanatının gündemine oturmuş, 20. Yüzyılın başlarına kadar etkisini sürdürmüştür.

Figürün resimdeki rolünün belirsizleştiği, ancak yok olmadığı bu süreçte, resim sanatının en güzel örneklerden birini, John Constable'ın 1821 yılında yaptığ 1 "Saman arabası" adlı eserinde görüyoruz (Görsel 17). Bu anlayış, Edouard Manet (1832-1883) ve arkadaşlarınca (Empresyonistler), resimde doğa odaklı bir yapıya yönelmiştir. Empresyonistler doğadaki renklerin zenginliğini tuvallerine yansıtmaları sonucunda, resim sanatında yeni bir anlayışla birlikte yeni bir tekniğe de öncülük etmişlerdir. Empresyonist teknik olarak adlandırılan bu yenilik sayesinde empresyonist ressamlar, resimdeki figür ve kompozisyonu, Leonardo da Vinci'nin sfumato tekniğine gerek duymadan betimleyebilme başarısını gösterebildiler. Böylece bu ressamlar, Rönesans'tan bu yana ilk kez, resimde betimlenen figürü tuvallerine aktarmada hiç olmadığı kadar özgür ve gelenekten uzak bir görüntü sergileyebildiler. İşte bu durum, 1800’lü yılları resim sanatında modern dönemin başlangıç yılları olarak kayda geçti.

Resim sanatında yaşanan bu değişimler ilgili çağdan tamamen bağımsız değildir. Bu bağlamda, 1800'lü yıllarda modern resmin başlangıcı olarak tanımlamamızda fotoğraf makinesinin keşfinin de dolaylı bir etkisinin olduğunu söyleyebiliriz. Bu etkiyle, Empresyonist ve Ekspresyonist ressamlar aynı bir fotoğraf meraklısının gezip dolaşırken beğendiği yerlerin fotoğrafinı çekmesine benzer biçimde resimde figür ve kompozisyona bağlı kalmadan modern resimler yaptılar. XIX. yüzyılın başlarında Pablo Picasso bu modern bağlamda, yaptı̆̆ 1 resimlerde kompozisyondan çok figüre ağırlık vererek ilerlemeye çalıştı (Görsel 23). Bu dönem resmi, Rönesans’tan bu yana betimlenen figür açısından, Picasso ve Munch gibi modern ressamların eserlerinde biçim olarak epeyce değişmiş oldu. Figürdeki bu çarpıcı değişime tanık olmak için Rönesans döneminin en önemli eserlerinden olan Leonardo da Vinci'nin (1503) Mona Lisa adlı tablosu ile Edward Munch'un Çığlık (1895) adlı eserini yan yana getirmek yeterli olacaktır (Görsel 28).

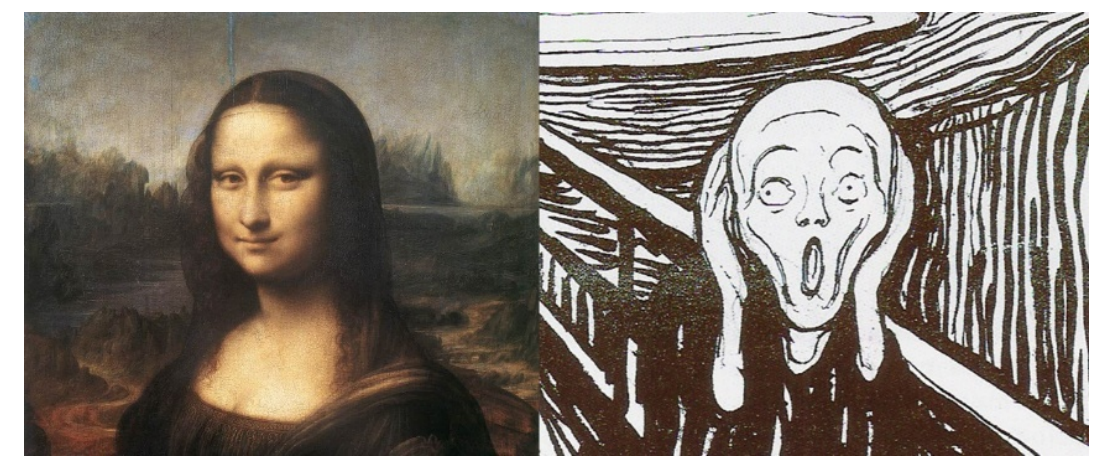

Görsel 28. Leonardo da Vinci'nin Mona Lisa (1503) tablosu ve Edward Munch 'un Çı̆̆llk(1895) adlı eserinin figür odaklı ayrintıları

Görsel 28'de görüldüğü gibi resimde figürün biçim olarak değişimi, Edward Munch'tan sonraki süreçte Vassily Kandinsky ile kompozisyon yönünde ilerlemiştir (bkz: Görsel 25). Böylece modernizmin resim sanatında başlattığı değişim, resamların zaman zaman figür ya da kompozisyon ögesini öne çıkartarak sürdürdüğü bir hal almıştır. Modern ressamların bu arayışları, Sürrealistlerin her iki ögenin de aynı tuvalde değişik sunumuyla sürdürülerek bir senteze varılmaya çalışılmıştır. Bu sentezde Sürrealistler resimdeki figür ve kompozisyon sorunsalına, gerçek dünyadan değil de bilinçaltı dünyasından (rüyalardan esinlenme) bir çözüm bulmaya çalıştılar. 
Resim sanatında halen içinde bulunduğumuz evrenin modern dönemin teknolojik gelişmelerle karma olduğu ileri bir aşaması olduğunu söyleyebiliriz. Bu evrede resim sanatı, fotoğraf makinesinden daha güçlü rakiplerle karşı karşıya olduğu bir var olma mücadelesi vermektedir. Bu evrede resim, kendi zaviyesinden hızlı teknolojik gelişmeler karşısında işe yarar çözümler üretmek zorundadır. Rönesans döneminden modern evreye en önemli tarihsel değişiklik de bu noktada ortaya çıkmaktadır: Rönesans'ta ressamlar yenilik peşinde koşarken, bilinen dünyadaki bilim ve teknolojiyi de peşlerinden sürüklemişlerdi. Oysa şu anki modern evrede ressamlar bilim ve teknolojinin peşinden gitmek, hatta koşmak zorundadırlar. Sonuç olarak, bir resim ister figür ister kompozisyon açısından ele alınsın, onun izleyiciyle bir konu bağlamında nasıl iletişime (görüntü ve anlam) geçtiği sorunsalı, geçmişte olduğu gibi gelecekte de yanıtının aranacağı zorlu bir alan olacağı açıktır.

\section{Kaynakça}

Akademi Portal. (2016). Erişim adresi: https://www.akademiportal.com/italyan-ressam-giotto-kimdiritalyan-ressam-giottonun-hayati/

Baroque art and architecture. (t.y.). Erişim adresi: https://www.britannica.com/art/Baroque-art-andarchitecture

Butler, D. L. \& Kline, M. A. (1998). Good versus creative solutions: A comparison of brainstorming, hierarchical, and perspective-changing heuristics. Creativity research journal, 11 (4), 325-331. Erişim adresi: http://dx.doi.org/10.1207/s15326934crj1104_6

Csikszentmihalyi, M. (2013). Creativity. Broadway, NY: Harper Perennial Modern Classics.

Gombrich, E. H. (2004). Sanatın öyküsü. (E. Erduran \& Ö. Erduran, Çev.). (4. Bask1). İstanbul: Remzi Kitabevi.

İnferno. (2015, 23 Mart). Yorum: Filippo Brunelleschi. [Blog yazıs1]. Erişim adresi: https://www.florenceinferno.com/filippo-brunelleschi/

Labno, J. (2008). Rönesans. (E. Dastarlı, Çev.). İstanbul: Türkiye İş Bankası Yayınları.

Newall, D. (2008). Empresyonistler-ayrıntıda sanat. (E. Dastarlı, Çev.). İstanbul: Türkiye İş Bankası Yayınları.

Ormond, B. (2011). Transformative shifts in art history teaching: the impact of standards-based assessment, The Curriculum Journal, 22(4), 567-590, Erişim adresi: https://doi.org/10.1080/09585176.2011.627225

Özbaşaran Dede, N. (2016, 12 Nisan). Picasso'nun “yeni bir şey öğrenmemişiz” dediği, 17 bin y1l öncesi mağaranın birebir kopyası [Blog yazısı. Erişim adresi: https://www.herkesebilimteknoloji.com/haberler/toplum/picassonun-yeni-bir-seyogrenmemisiz-dedigi-17-bin-yil-oncesi-magaranin-birebir-kopyasi

Rococo Art Style. (t.y). Erişim adresi: http://www.visual-arts-cork.com/history-of-art/rococo.htm

Sunal, B. (2016, 24 Aralık). Barok sanatı nedir? [Blog yazısı]. Erişim adresi: https://www.makaleler.com/barok-sanati-nedir

Tepecik, A. (2002). Grafik sanatlar. Ankara: Detay \& Sistem ofset.

Varlık Şentürk, L. (2012) Analitik resim çözümlemeleri. İstanbul: Ayrıntı Yayınları.

\section{Görsel Kaynakçası}

Görsel 1. Bondone, G. (Sanatç1). (1305) İnanç / Faith [Fresk]. Kaynak: Gombrich, E. H. (2004). Sanatın öyküsü. (E. Erduran \& Ö. Erduran, Çev.). (4. Bask1). İstanbul: Remzi Kitabevi. (s. 201). 
Görsel 2. Martini, S. \& Memmi, L. (Sanatç1). (1333). Meryem'e Müjde / The Annunciation [Pano]. Kaynak: Gombrich, E. H. (2004). Sanatın öyküsü. (E. Erduran \& Ö. Erduran, Çev.). (4. Bask1). İstanbul: Remzi Kitabevi. (s. 213).

Görsel 3. Masaccio. (Sanatç1). (1425-28). Kutsal Üçlü / Holy Trinity [Fresko]. Erişim adresi: https://www.wga.hu/index $1 . h t m l$

Görsel 4. Uccello, P. (Sanatçı). (1432). San Romano Savaşı / Battle of San Romano [Pano]. Erişim adresi: https://www.wga.hu/index1.html

Görsel 5. Francesca, P. D. (Sanatçı). (1460). İsa'nın Dirilişi / The Resurrection [Fresk]. Erişim adresi: https://www.wga.hu/index 1.html

Görsel 6. Pollaiuolo, A. (Sanatçı). (1475), Aziz Sebastianus”un Şehit Edilişi / Martyrdom of Saint Sebastian [Pano]. Erişim adresi: https://www.wga.hu/index1.html

Görsel 7. Vinci, L. (Sanatçı). (1503), Mona Lisa / Mona Lisa [Yağlı boya]. Erişim adresi: https://www.wga.hu/index 1.html

Görsel 8. Vecellio, T. (Sanatçı). (1516-18), Meryem'in Göğe Yükselişi / Pala Dell Assunta [Yağlı boya]. Erişim adresi: https://www.wga.hu/index1.html

Görsel 9. Vecellio, T. (Sanatçı). (1519-26), Azizlerle Meryem (Pesaro Madonnası) / Pala Pesaro [Yağl1 boya]. Erişim adresi: https://www.wga.hu/index1.html

Görsel 10. Parmigianino, F. (Sanatç1). (1534-40), Uzun boyunlu Meryem / Madonna with long neck [Yağlı boya]. Erişim adresi: https://www.wga.hu/index1.html

Görsel 11. Bruegel, P. (Sanatçı). (1567), Köy dügünü / Peasant Wedding [Yağlı boya]. Erişim adresi: https://www.wga.hu/index 1.html

Görsel 12. El Greco. (Sanatçı). (1608-14), Beşinci Mührün Açılışı / The Opening of the Fifth Seal (The Vision of St John) [Yağlı boya]. Erişim adresi: https://www.wga.hu/index 1.html

Görsel 13. Caravaggio, M. M. (Sanatçı). (1602-1603), İsa'nın Mezara İndirilişis / The Entombment of Christ [Yağlı boya]. Erişim adresi: https://www.wga.hu/index1.html

Görsel 14. Vermeer, J. (Sanatçı). (1658), Süt Döken kadın / The Milkmaid [Yağlı boya]. Erişim adresi: https://www.wga.hu/index 1.html

Görsel 15. Watteau, J. A. (Sanatçı). (1716-19), Açık havada eğlence / Merry company in the open air [Yağlı boya]. Erişim adresi: https://www.wga.hu/index1.html

Görsel 16. Mengs, A. R. (Sanatç1). (1763), Kutsal Aile / The Holy Family with the Infant St John the Baptist [Yağlı boya]. Erişim adresi: https://www.wga.hu/index1.html

Görsel 17. Constable, J. (Sanatçı). (1821), Saman arabası / The Hay Wain [Yağlı boya]. Erişim adresi: https://www.wga.hu/index 1.html

Görsel 18. Courbet, G. (Sanatçı). (1854), Günaydın Bay Courbet / Bonjour Monsieur Courbet [Yağlı boya]. Erişim adresi: https://www.wga.hu/index1.html

Görsel 19. Millet, J. F. (Sanatçı). (1857), Başak Toplayan Kadınlar / The Gleaners [Yağlı boya]. Erişim adresi: https://www.wga.hu/index1.html

Görsel 20. Monet, C. (Sanatçı). (1874), İzlenim / Impression Sunrise [Yağlı boya]. Erişim adresi: https://www.wga.hu/index 1.html 
Görsel 21. Cezanne, P. (Sanatçı). (1885), Sainte-Victoire dağının Bellevue'den görünüşü / Montagne Sainte-Victoire [Yağlı boya]. Kaynak: Gombrich, E. H. (2004). Sanatın öyküsü. (E. Erduran \& Ö. Erduran, Çev.). (4. Baskı). İstanbul: Remzi Kitabevi. (s. 540).

Görsel 22. Van Gogh, V. (Sanatçı). (1889), Sanatçının Arles'daki odası / The Bedroom [Yağlı boya]. Erişim adresi: https://www.wga.hu/index1.html

Görsel 23. Picasso, P. (Sanatçı). (1912), Keman ve üzümler / Violin and Grapes [Yağlı boya]. Kaynak: Gombrich, E. H. (2004). Sanatın öyküsü. (E. Erduran \& Ö. Erduran, Çev.). (4. Bask1). İstanbul: Remzi Kitabevi. (s. 575).

Görsel 24. Munch, E. (Sanatç1). (1895), Çığlık / Skrik [Taş baskı]. Kaynak: Gombrich, E. H. (2004). Sanatın öyküsü. (E. Erduran \& Ö. Erduran, Çev.). (4. Baskı). İstanbul: Remzi Kitabevi. (s. 565).

Görsel 25. Kandinsky, V. (Sanatçı). (1910-11), Kazaklar / Cossacks [Yağl1 boya]. Kaynak: Gombrich, E. H. (2004). Sanatın öyküsü. (E. Erduran \& Ö. Erduran, Çev.). (4. Bask1). İstanbul: Remzi Kitabevi. (s. 570).

Görsel 26. Modrian, P. (Sanatçı). (1920), Kırmızı, siyah, mavi, sarı ve griyle düzenleme / Composition with red, black, blue, yellow, and gray [Yağlı boya]. Kaynak: Gombrich, E. H. (2004). Sanatın öyküsü. (E. Erduran \& Ö. Erduran, Çev.). (4. Baskı). İstanbul: Remzi Kitabevi. (s. 583).

Görsel 27. Dali, S. (Sanatçı). (1938), Bir yüzün ve bir meyve kâsesinin kumsaldaki hayali / Apparition of face and fruit dish on a beach [Yağl1 boya]. Kaynak: Gombrich, E. H. (2004). Sanatın öyküsü. (E. Erduran \& Ö. Erduran, Çev.). (4. Bask1). İstanbul: Remzi Kitabevi. (s. 593).

Görsel 28. Vinci, L. (Sanatç1). (1503), Mona Lisa / Mona Lisa [Yağlı boya]. Erişim adresi: https://www.wga.hu/index1.html \& Munch, E. (Sanatç1). (1895), Çı̆̆lık/ Skrik [Taş bask1]. Kaynak: Gombrich, E. H. (2004). Sanatın öyküsü. (E. Erduran \& Ö. Erduran, Çev.). (4. Bask1). İstanbul: Remzi Kitabevi. (s. 565). 